\title{
PECULIARITIES OF CREATING INTERACTIVE EDUCATIONAL ENVIRONMENT IN VOCATIONAL TRAINING OF FUTURE MEDICAL SPECIALISTS
}

I. М. Мельничук

\author{
Тернопільський національний медичний університет \\ імені І. Я. Горбачевського МОЗ України
ОСОБЛИВОСТІ СТВОРЕННЯ ІНТЕРАКТИВНОГО ОСВІТНЬОГО СЕРЕДОВИЩА У ПРОФЕСІЙНІЙ ПІДГОТОВЦІ МАЙБУТНІХ \\ ФАХІВЦІВ МЕДИЦИНИ
}

\begin{abstract}
The article deals with the actuality of creating interactive educational environment in vocational training of future specialists of medical field. The interactive study is considered in a context of pedagogical dialogue and cooperation. It has been generalized that interactive learning dialogue gives an opportunity for lecturers to establish the level of understanding theoretical material by future specialists, to identify the formation of students' abilities and skills. Students can explain the essence, specific, direction and purpose of performing certain professional actions that is of particular importance in the vocational training of future medical specialists.

The use of interactions in medical institutions of higher education contributes to the creation of interactive learning environment and is directed to stimulation of mental, emotional, social activity and independence in the practical activities of students. The main features of interactive learning environment have been specified: high level of communication intensity of its participants; dynamic and variety of types, forms and methods of communicative interaction; purposeful reflection of lecturers and students of their actions and organized interaction. It has been generalized that interactive technologies are technologies of cooperation of the subjects of pedagogical interaction. Therefore, interactive learning is considered a pedagogical process, which is a set of regular, consistent active interactions between a lecturer and students in order to develop them. Such as development is internal, personal process, which is, first of all, regulated by the student (self-development), the main function of the lecturer, in the process of interactive learning, is creating optimal conditions for student's self-development, development of his/her individuality, subjectivity and adjustment of this process.

The basis of interactive learning is dialogue interrelations. Dialogue in the interactive learning is considered as communicative process of real or imaginary partners, during which information is exchanged, identifying points of view, meaningful positions, value orientations and personal meanings of the participants of interactive cooperation are revealed.
\end{abstract}

Key words: interactive learning; higher education; medical field specialists; lecturer; education; dialogue; interactions.

Анотація. У статті аргументовано актуальність створення інтерактивного навчального середовища у професійній підготовці майбутніх фахівців медичної галузі. Інтерактивне навчання розглядається в контексті педагогіки діалогу та співробітництва. Узагальнено, що діалогічність інтерактивного навчання дає змогу викладачам встановити рівень розуміння майбутніми фахівцями теоретичного матеріалу, виявити сформованість умінь і навичок студентів. Студенти можуть пояснити сутність, специфіку, спрямованість і мету виконання окремих професійних дій, що набуває особливої значущості в професійній підготовці майбутніх фахівців медичної сфери.

Використання інтеракцій у медичних закладах вищої освіти сприяє створенню інтерактивного навчального середовища і спрямовується на стимулювання розумової, емоційної, соціальної активності та самостійності в практичній діяльності студентів. Конкретизовано основні ознаки інтерактивного навчального середовища, такі, як: високий рівень інтенсивності спілкування його учасників; динаміка та різноманітність видів, форм і прийомів комунікативної взаємодії; цілеспрямована рефлексія викладачів і студентів своїх дій та організованої взаємодії. Узагальнено, що інтерактивні технології $є$ технологіями співпраці суб'єктів педагогічної взаємодії. Відтак інтерактивне навчання розглядається як педагогічний процес, що є сукупністю закономірних, послідовних активних взаємодій викладача і студентів з метою їх розвитку. Оскільки розвиток є процесом внутрішнім, особистісним, що регулюється перш за все самим студентом (саморозвиток), основною функцією викладача в процесі інтерактивного навчання є створення оптимальних умов для саморозвитку студента, розвитку його індивідуальності, суб’єктності та корегування цього процесу.

(C) I. M. Melnychuk 


\title{
Materials of International Scientific and Practical Conference \\ "PROFESSIONAL AND COMMUNICATION CULTURE OF THE FUTURE DOCTOR: LINGUISTIC, PEDAGOGICAL AND PHILOSOPHICAL ASPECTS”
}

\begin{abstract}
Основою інтерактивного навчання є діалогові взаємини. Діалог в інтерактивному навчанні розглядається як комунікативний процес реальних або уявних партнерів, у ході якого відбувається обмін інформацією, виявлення точок зору, смислових позицій, ціннісних орієнтацій та особистісних смислів учасників інтерактивної взаємодії.
\end{abstract}

Ключові слова: інтерактивне навчання; вища школа; фахівці медичної галузі; викладачі; освіта; діалог; інтеракції.

Introduction. The relevance of creating interactive learning environment in higher education is conditioned by the fact that each participant of educational interaction becomes more active in cognition, the active subject of "self-adoption ... and the seeker of truth" [5]. The basis of interactive learning is organized information exchanged on the basis of dialogic interaction between lecturer and students. That is why interactive learning is considered in the context of pedagogy of dialogue, pedagogy of cooperation. The role of lecturer is in organization of a successful pedagogical interaction. Modern educator should take into account personal qualities of students that are constantly transformed under the influence of external circumstances and individual growth [7]. Dialogue of interactive learning gives possibility for lecturer to define the level of understanding theoretical material by future specialists, to identify formation of students' abilities and skills. Students have got opportunity not only demonstrate professional abilities, but also explain the essence, specificity, orientation and purpose of performing individual professional actions, which is of particular importance in the vocational training of future specialists of medicine.

The aim is in substantiation of specifics of creating interactive educational environment in higher medical school.

Methods. Historical analysis of scientific literature has testified that the notion of "interactive pedagogy" was introduced in 1975 [6]. However, the foundations of interactive learning were laid in Ancient Greece. In particular, Socrates' dialogues with students (470399 BC) are a kind of conversation-investigation, subordinated to the search for truth, the process of formulating right question and specifically concrete answer for it. It is from Socrates that dialogue begins as the philosophical art of reasoning in order to establish truth. Socrates' method of philosophizing is to use the right questions to clarify the boundaries of knowledge and ignorance of the interlocutor and to direct him to true knowledge that is evidenced in the famous slogan of Socrates "Know thyself".

Analysis of scientific literature shows that since 90s of the XX century researches were purposefully carried out with the purpose of argumentation of interactive learning advantages and development of methods of its organization in pedagogical society.

Theoretical analysis of pedagogical investigations of many scholars (L. Ampilohova, M. Klarin, O. Komar, L. Pyrozhenko, O. Pometun, V. Skrypnyk, N. Suvorova, etc.) gave the opportunity to establish that interactive learning is seen as a compulsory aspect of modern education. Researchers paid a particular attention to the use of interactive learning in higher education (L. Artemova, K. Hiria, T. Dutkevych, I. Melnychuk, I. Osadchenko, etc.). It has been stated that interactive learning is of particular importance in the training of future specialists of socio-economic professions (teachers, doctors, nurses, etc.), where interpersonal interaction is the basis of professional activity.

Generalization of the essence of literary sources gave a possibility to determine the availability of fundamental scientific studies, which can be used by lecturers of higher education of non-pedagogical profile (for example, in medical universities and colleges) in order of organizing interactive educational environment. This is an interactive textbook for educators of the market-based education system (by I. Pidlasyi); "Interactive learning encyclopedia" (by O. Pometun); conceptual and terminological analysis of basic definitions of interactive learning (by M. Skrypnyk) etc.

Results. Clarifying the essence of the concept of "interactive" (where "inter" - mutual and "act" - to act, to do) made it possible to generalize that this notion is used in understanding the ability to interact. Accordingly, the creation of interactive learning environment involves the realization of such pedagogical conditions under which the active interaction of all subjects of the educational process takes place. According to scientists, interaction is "a developmental study process in the context of dialogue, active interaction and communication of its participants" [3]. Use of interactions provides creation of interactive educational environment and aims to stimulate the following types of student activity:

- mental, manifested in the activation of logical thinking, generation of ideas, expression of assumptions, design, construction, modeling, research, expression of creative imagination, focus, attention, observation, implementation of analytical and synthetic operations; 


\section{Materials of International Scientific and Practical Conference \\ "PROFESSIONAL AND COMMUNICATION CULTURE OF THE FUTURE DOCTOR: LINGUISTIC, PEDAGOGICAL AND PHILOSOPHICAL ASPECTS”}

- emotional, which is reflected in the emergence of emotional tension, experiences, formation of selfconfidence;

- social, which is in imitation of implemetation of social roles, exchange of opinions, expressing one's own judgments and conclusions, personal attitude to facts, phenomena and activities on the basis of critical thinking, formation of humanistic values, communicative competence;

- activity in the independent practice - first in conditions of study, and in future - in conditions of professional functions. Scientists argue that identifying these types of students' activities will promote their personal development, self-determination, personalization, social identification, formation of professional mentality [4].

Creation of interactive learning environment in higher education is directed to the development of students' abilities in professional communication, which is especially important for future specialists in medicine. It is in the process of implementing relevant professional roles in simulated interactive professional situations future doctors and nurses are able to reproduce optimal examples of professional action in collaboration with colleagues and patients. In this way, students get practical experience of professional communication during their studies.

Pedagogical process of interactive learning - is always organized phenomenon, which includes different types of lecturers' and students' activities. The lecturer's role is in development of clear methods of interactive class that involves a coherent logic, order, interconnection, determinism and sequence of actions, which testifies to the technology and systematic nature of interactive learning. The major educator's task in creating interactive learning environment is to organize work of all participants of interactive cooperation and always aims to develop student as future specialist. The dynamic of formation of professional qualities (knowledge, abilities, skills, motives for self-development and personal growth as medical specialist, etc.) in students is fixed by means of diagnostics. Therefore, we consider interactive learning as an innovative and technological pedagogical process, which is a system of regular, consistent active interactions, joint activity of lecturer and students for the purpose of their development. The main features of interactive learning environment are:

- spatial (training audience) and temporal (scheduled classes according to the curriculum and time-table) coexistence of participants of interactive learning, which leads to the organization of productive educational interpersonal interaction, predetermined by the task of a particular class;

- awareness of the general purpose, the intended activity result, according to the everyone's interests and contributes to the realization of everyone's needs;

- planning, control, correction and coordination of students' actions in the process of interactive learning;

- involvement of each student to the process of joint activities through the distribution of functions and roles in the process of cooperation;

- emergence of new models of interpersonal relationships that can be used in future professional activity of medical specialist.

As the interpersonal communication of lecturer as a subject of his/her professional activity and students as subjects of their own educational activity is activated, the interactive learning environment has the following characteristics:

- high level of intensity of its participants' communication and activities exchange (presenting by lecturer problem tasks and professional situations for medical workers; proving students' own understanding of the problems identified and substantiating the ways of their solution; demonstrating by students the samples of optimal professional actions, etc.);

- dynamics and variety of types, forms and methods of communicative interaction that give a possibility to refocus students' attention on different activities (for example, theoretical analysis of professional problems relevant to the topic of class and the expression of own ideas (interactive methods of "Bank of ideas", "Brain storming”)), which can be used for deciding professional tasks;

- purposeful reflection of lecturers and students of their actions and organized interaction that promotes students' awareness and assimilation of optimal samples of professional activity, and allows teachers to make certain adjustments into methodic of further organization of interactive educational environment.

Thus, interactive pedagogical cooperation is directed to the improvement of behavior models and activities of pedagogical process participants [2]. That is why the main purpose of organization of interactive learning environment in medical institutions of higher education is creating by lecturer such conditions of vocational training of future doctors or nurses, according to which every student will feel his/her success, intellectual ability, realization of natural potential, will 


\section{Materials of International Scientific and Practical Conference \\ "PROFESSIONAL AND COMMUNICATION CULTURE OF THE FUTURE DOCTOR: LINGUISTIC, PEDAGOGICAL AND PHILOSOPHICAL ASPECTS”}

independently acquire knowledge and will construct his/her own professional competence in the process of professional development.

Generalizing the direction of interactive learning, scholars view it in the following contexts:

- dialectical process, which contributes to personal and professional development of future specialists in the period of obtaining higher education;

- studying that is simultaneously characterized by information and activity content;

- complex of methods that have general educational, professional, socio-psychological, pedagogical, cultural essence;

- studying that is based on the associative-reflexive mechanism of getting knowledge, abilities and skills, necessary in future professional activity of medical specialists;

- anthropocentric, sociogenic phenomenon by the main factor of development and attitude to personality;

- innovative process, due to which classes take place with using active forms of problem and dialogic learning - problem lectures, seminars, brain storming, psychodrama, disputes, debates, dialogues, polylogues, press conferences, business and didactic games, staging, trainings, etc. [4].

The important aspect in organization of interactive learning environment in higher education is compliance by lecturers with the requirements:

- to take into account high efficiency of interactive cooperation in pedagogical practice;

- to identify the criteria of the effectiveness of interaction that reflects not only tendencies in the modernization of future medical workers' training, but also meets the main purpose and tasks of concrete class;

- to choose such interactive methods, which will be optimal for training of future specialists of the concrete specialty (doctors, dentists, pharmacists, nurses, etc.) in higher education;

- to use only those interactive methods and techniques, which will meet the goals and tasks of students' personal development and training of future specialists;

- to use interactive methods provided systematic and availability of their application.

Interactive learning in higher education is based on a dialogical approach that is why interactive technologies are technologies of cooperation of subjects of pedagogical interaction. Therefore, interactive learning is seen as a pedagogical process, which is a complex of regular, consistent active interactions between the lecturer and students in order to develop them.

Since development is internal, personal process, governed primarily by the student (self-development), the main function of the lecturer in the process of interactive learning is to create optimal conditions for the student's self-development, the development of his/her personality, subjectivity and correction of this process, "in order to develop human - the subject of his/her own life strategy" [2].

Dialogue interrelations form the basis of interactive learning at the modern stage of dialogic development (as a science of organization and conducting conversations). Dialogue in the interactive learning can be seen as a communicative process of real or imaginary partners, in the process of which not only information is exchanged but points of view, semantic positions, values and personal meanings of partners are revealed. The result of such dialogue - is synthesis of new sense, which appears in the process of collisions of different semantic positions of communication partners [1]. Therefore, interactive learning should be considered as one of the variants (models) of communication technologies with a well-organized feedback of subjects and learning objects, with two-way exchange of information between them on the basis of dialogic interaction.

Conclusions and Prospects for Research. Thus, creation of interactive learning environment in medical school has certain features. Taking into account of such specialties provides for acquaintance of lecturers with the essence of interactive learning and the specifics of its use in higher education. Therefore, for the efficient use of modern pedagogical interactive forms and methods in vocational training of future specialists of medical field is necessary to train lecturers for creating optimal interactive learning environment. It is advisable, for this purpose, systematically to conduct educational trainings to familiarize scientific and pedagogical staff of medical schools with modern pedagogical technologies, in particular, with technologies of interactive learning.

The prospects for further scientific researches we see in the development of methodological support for the organization of educational trainings for lecturers of medical schools in order to increase pedagogical skills in using interactive pedagogical technologies. 


\section{List of literature}

1. Бахтин М. М. Эстетика словесного творчества / М. М. Бахтин. - М. : Искусство, 1979. - 424 с.

2. Кашлев С. С. Технология интерактивного обучения / С. С. Кашлев. - Мн. : Белорусский верасень, 2005. 196 с.

3. Мельник В. В. Інтеракція в освітньому процесі: технологія організації / В. В. Мельник // Управління школою. - 2006. - № 23 (133). - С. 15-35.

4. Мельничук I. М. Теорія і методика професійної підготовки майбутніх соціальних працівників засобами інтерактивних технологій у вищих навчальних закладах :

\section{References}

1. Bakhtin, M.M. (1979). Estetika slovesnogo tvorchestva [Aesthetics of verbal creativity]. Moscow: Iskusstvo [in Russian].

2. Kashlev, S.S. (2005). Tehnologiya interaktivnogo obucheniya [Interactive learning technology]. Minsk: Belorusskiy verasen [in Russian].

3. Melnyk, V.V. (2006). Interaktsiia v osvitnomu protsesi: tekhnolohiia orhanizatsii [Interaction in the educational process: technology of organization]. Upravlinnia shkoloiu - School Management, 23 (133), 15-35 [in Ukrainian].

4. Melnychuk, I.M. (2011). Teoriia i metodyka profesiinoi pidhotovky maibutnikh sotsialnykh pratsivnykiv zasobamy interaktyvnykh tekhnolohii u vyshchykh navchalnykh zakladakh [Theory and methods of future social workers pro- дис. ... доктора пед. наук : 13.00.04 / І. М. Мельничук. Тернопіль, 2011. - 585 с.

5. Підласий І. П. Практична педагогіка або три технології : інтерактивний підручник для педагогів ринкової системи освіти / І. П. Підласий. - К. : Видавничий Дім «Слово», 2004. - 616 с.

6. Пометун О. І. Енциклопедія інтерактивного навчання / О. І. Пометун. - К., 2007. - 144 с.

7. Ягупов В. В. Педагогіка : навч. посіб. / В. В. Ягупов. - К. : Либідь, 2003. - 560 с.

fessional training by means of interactive technologies in the education of high learning]. Doctor's thesis. Ternopil [in Ukrainian].

5. Pidlasyi, I.P. (2004). Praktychna pedahohika abo try tekhnolohii: interaktyvnyi pidruchnyk dlia pedahohiv rynkovoi systemy osvity [Practical pedagogy or three technologies: interactive textbook for educators of the marketbased education system]. Kyiv: Vydavnychyi Dim "Slovo" [in Ukrainian].

6. Pometun, O.I. (2007). Entsyklopediia interaktyvnoho navchannia [Interactive learning encyclopedia]. Kyiv [in Ukrainian].

7. Yahupov, V.V. (2003). Pedahohika [Pedagogy]. Kyiv: Lybid [in Ukrainian]. 